Daniel Karthe ${ }^{1}$, Nikolay S. Kasimov ${ }^{2}$, Sergey R. Chalov ${ }^{3}$, Galina L. Shinkareva ${ }^{4}$, Marcus Malsy ${ }^{5}$, Lucas Menzel ${ }^{6}$, Philipp Theuring ${ }^{7}$, Melanie Hartwig ${ }^{8}$, Christian Schweitzer9, Jürgen Hofmann ${ }^{10}$, Jörg Priess ${ }^{11}$, Mikhail Lychagin ${ }^{12}$

${ }^{1}$ Department of Aquatic Ecosystem Analysis and Management, Helmholtz Centre for Environmental Research, Magdeburg, Germany; Brückstr. 3a, 39114 Magdeburg, Ph. +49-391-810-9104, daniel.karthe@ufz.de

2 Faculty of Geography, Lomonosov Moscow State University, Moscow, Russia; Leninskie Gory, 1, 119991, Ph. +7 495 9392238, secretary@geogr.msu.ru

3 Faculty of Geography, Lomonosov Moscow State University, Moscow, Russia; Leninskie Gory, 1, 119991, Ph. +7 495 9391552,

srchalov@rambler.ru

* Corresponding author

${ }^{4}$ Faculty of Geography, Lomonosov Moscow State University, Moscow, Russia; Leninskie Gory, 1, 119991, Ph. +7 495 9394407, galina.shinkareva@gmail.com

${ }^{5}$ Center for Environmental Systems Research, Kassel University, Kassel, Germany; Wilhelmshöher Allee 47, 34109 Kassel, Ph. +49-561-804-6122, malsy@usf.uni-kassel.de 6 Department of Hydrogeography and Climatology, Heidelberg University, Heidelberg, Germany; Im Neuenheimer Feld 348, 69120 Heidelberg,

Ph. +49-6221-54-5583, lucas.menzel@geog.uni-heidelberg.de

7 Department of Aquatic Ecosystem Analysis and Management, Helmholtz Centre for Environmental Research, Magdeburg, Germany; Brückstr. 3a, 39114 Magdeburg, Ph. +49-391-810-9670, philipp.theuring@ufz.de

8 Department of Aquatic Ecosystem Analysis and Management, Helmholtz Centre for Environmental Research, Magdeburg, Germany; Brückstr. 3a, 39114 Magdeburg, Ph. +49-391-810-9670, melanie.hartwig@ufz.de

${ }^{9}$ Department of Computational Landscape Ecology, Helmholtz Centre for Environmental Research, Permoserstraße 1, 04318 Leipzig, Germany.

Ph: +49-341-235-1962, christian.schweitzer@ufz.de

10 Leibniz Institute of Freshwater Ecology and Inland Fisheries (IGB), Department Ecohydrology, Müggelseedamm 310, 12587, Germany; Ph. +49-30 - 6392 4073, j.hofmann@igb-berlin.de

11 Department of Computational Landscape Ecology, Helmholtz Centre for Environmental Research, Permoserstraße 1, 04318 Leipzig, Germany.

Ph: +49-341-235-1879, joerg.priess@ufz.de

12 Faculty of Geography, Lomonosov Moscow State University, Moscow, Russia; Leninskie Gory, 1, 119991, Ph.+7 495 9394047, lychagin2008@gmail.com

\title{
INTEGRATING MULTI-SCALE DATA FOR THE ASSESSMENT OF WATER AVAILABILITY AND QUALITY IN THE KHARAA - ORKHON - SELENGA RIVER SYSTEM
}

ABSTRACT. The environmental and socioenonomic impacts of water pollution are particularly severe in regions with relatively limited water resources [WWAP, 2012].
Water quantity and quality are closely interlinked aspects which are relevant for surface water ecology, water use, and integrated management approaches. 
However, an intensive monitoring of both is usually prohibitive for very large areas, particularly if it includes the investigation of underlying processes and causes. For the Kharaa - Orkhon - Selenga River system, this paper combines results from the micro (experimental plots, individual point data), meso (Kharaa River Basin) and macro (Selenge River Basin) scales. On the one hand, this integration allows an interpretation of existing data on surface water quantity and quality in a wider context. On the other hand, it empirically underpins the complimentary character of intensive monitoring in selected model regions with more extensive monitoring in larger areas.

KEY WORDS: hydrology; water availability; water quality; Central Asia; Mongolia; Russia

\section{INTRODUCTION}

The Kharaa, Orkhon and Selenga rivers (Table 1), which are located in northern Mongolia and southern Siberia, are not only parts of the same major river system draining into Lake Baikal, but their basins are in many ways comparable with regard to the physical environment and socio-economic development [Karthe et al., 2013]. Due to its moderate size $\left(15000 \mathrm{~km}^{2}\right)$, the Kharaa River Basin could be intensively studied in the context of a German-Mongolian research project which aimed at the development of the scientific basis for a locally adapted IWRM concept [MoMo Consortium, 2009; Karthe et al., 2012]. The Kharaa River originates at the confluence of Mandalin Gol and Sugnugur Gol, draining from the western parts of the Khentii mountains. It is a tributary of the Orkhon River, into which it flows just downstream of Darkhan, Mongolia's second largest city. The Orkhon River is Mongolia's longest stream, and some of its tributaries, most notably the Tuul and the Kharaa Rivers, meander through the country's most densely settled regions. A River Basin Management Plan which was recently developed in cooperation between the Mongolian environmental ministry and a Dutch consultancy project provides an overview of existing information (and knowledge gaps) for this basin[MEGD, 2012]. Near Sukhbaatar and just before the Russian-Mongolian border, the Orkhon River drains into the Selenga, which then flows northward and forms a wide delta before draining into Lake Baikal [Kasimov et al., 2010]. Synoptic research on the Selenga River Basin was recently carried out by research projects involving Russian, Mongolian, Swedish and Korean scientists [Chalov et al., 2012; Thorslund et al., 2012; Mun et al., 2008].

\section{WATER AVAILBILITY AND ITS DETERMINANTS}

The northern part of Mongolia and the southern part of Siberia, where the Kharaa Orkhon - Selenga river system is located, are characterized by a highly continental climate with very cold winters and a limited natural water availability [Menzel et al., 2011]. The potential evapotranspiration exceeds the annual precipitation by a factor of almost 3 . This chapter first summarizes important links between climate and water availability in the region, including the impacts of climate change, which are expected to be stronger

Table 1. Characteristics of the Kharaa, Orkhon and Selenga river basins

\begin{tabular}{|l|c|c|c|}
\hline & Kharaa & Orkhon & Selenga \\
\hline Length of river & $362 \mathrm{~km}$ & $1066 \mathrm{~km}$ & $1024 \mathrm{~km}$ (1453 km incl. Ider) \\
\hline Catchment area & Ca. $15000 \mathrm{~km}^{2}$ & Ca. $54000 \mathrm{~km}^{2}$ & Ca. $450000 \mathrm{~km}^{2}$ \\
\hline Average runoff near outlet (MQ) & $12.1 \mathrm{~m}^{3} / \mathrm{s}$ & $124.5 \mathrm{~m}^{3} / \mathrm{s}$ & $897 \mathrm{~m}^{3} / \mathrm{s}$ \\
\hline Population & Ca. 147,000 inhabitants & Ca. 236000 inhabitants & Ca. 2439000 inhabitants \\
\hline
\end{tabular}

Sources: Mun et al., 2008; MoMo Consortium, 2009; Garmaev et al., 2010; Potemkina, 2011; Kasimov et al., 2010 ; MEGD, 2012; Thorslund et al., 2012 
for East-Central Asian drylands than in other parts of the world [IPCC, 2007]. The following section addresses hydrological trends observed in different parts of the river system and demonstrates that the meso-scale Kharaa River Basin is a suitable model region for the macro-scale Selenga River Basin. For this model region, a third subchapter analyzes the dynamics of land use change at river basin scale, including their hydrological relevance. A more detailed discussion of hydrometeorological processes and landcover in the basin's headwater region is presented in the chapter's last section.

\section{Water Availability in the Selenga - Baikal Basin and Expected Impacts of Climate Change}

The Central Siberian Plateau, including the Lake Baikal Basin, is one of the regions where the effects of global climate change are particularly marked [Clarke et al., 2007]. Mean annual air temperatures increased in the lake area by 1,2K during the 20th century. The air temperature change over the entire river basin is probably higher due to the balancing impacts of the Lake Baikal water body. During the same time, mean annual precipitation increased by $59 \mathrm{~mm}$, both with a considerable regional and interannual variability. On the one hand, this led to an inflow increase of $17 \%$ during the last century. On the other hand, both ice duration ( -11 days) and ice thickness $(-24 \mathrm{~cm})$ on Lake Baikal decreased notably during this period [Shimaraev et al., 2002].

In order to assess the regional pattern and trends of water availability, (1) recent freshwater resources were simulated using the WaterGAP3 model (Water - Global Assessment and Prognosis) and WATCH forcing data and (2) changes in temperature and precipitation were shown for 2071 to 2100 using WATCH driving data based on three global circulation models (GCMs). The simulation of recent freshwater resources (baseline time period 1971-2000) was conducted with the large-scale hydrology and water use model WaterGAP3. WaterGAP3 is a further development of WaterGAP2 [Alcamo et al., 2003; Döll et al., 2003] and operates on a five arc minute grid $\left(\sim 6 \times 9 \mathrm{~km}^{2}\right)$ in daily internal time steps [Verzano, 2009]. In this study a landmask derived from river basins for the Lake Baikal river system has been applied. The calibration and validation of the model was done with the global meteorological dataset WATCH forcing data (WFD). The WFD is based on a half degree grid in daily time steps [Weedon et al., 2011] and was rescaled to the model resolution of five arc minutes. The water use model contains five sub models for the calculation of water abstractions in the sectors irrigation, livestock, domestic, manufacturing, and thermal electricity production [aus der Beek, 2010; Flörke, 2013]. As scenario data for the time period 2071-2100 the WATCH driving data (WDD) set was used, which consists of transient bias corrected climate change projections. This dataset is available for the A2 and B1 IPCC-SRES Scenarios (IPCC 2000) and three GCMs (IPSL, ECHAM5 and CNCM3) [Hagemann et al., 2011; Piani et al., 2010].

Modelled mean annual water availability of Lake Baikal inflows (Fig. 1) shows the lowest water availability in the Tuul and Khilok river basins, while the upper Angara catchment features the highest water availability. The mean annual water availability for the Lake Baikal Basin is $83 \mathrm{~mm}$, but with a large regional variation. This is due to mean annual air temperatures ranging from $-11,4^{\circ} \mathrm{C}$ to $+1,0^{\circ} \mathrm{C}$, and mean annual precipitation ranging from $188 \mathrm{~mm}$ to 872 $\mathrm{mm}$. Both the $\mathrm{A} 2$ and $\mathrm{B} 1$ scenario predict an increase of precipitation (ranges 241 $\mathrm{mm}$ to $1109 \mathrm{~mm}$ and $211 \mathrm{~mm}$ to $1015 \mathrm{~mm}$, respectively) until the end of 21 st century. The highest increase is predicted for the southern shore of Lake Baikal, while the lowest increase is expected for the Tuul river basin according to the A2 scenario and in the headwater region of the Ider and Chuluut rivers according to the B1 scenario. Both scenarios predict a significant rise of mean annual air temperature for the entire Lake Baikal basin (ranges from $-6,2$ to $+6,5^{\circ} \mathrm{C}$ for $\mathrm{A} 2$, and $-8,2$ to $+4,5^{\circ} \mathrm{C}$ for $\mathrm{B} 1$ ). 
This substantial temperature and precipitation increase is likely to have various direct and indirect effects on regional hydrology, such as increasing evapotranspiration, permafrost thawing, and decline of the snow layer. Anisimov \& Reneva
[2006] expect that the area of near-surface permafrost will decrease by 18\% until 2050. Using simulations based on the WaterGAP3 model, Malsy et al. [2012] have shown for the Mongolian part of the basin that water availability will increase until the end of the

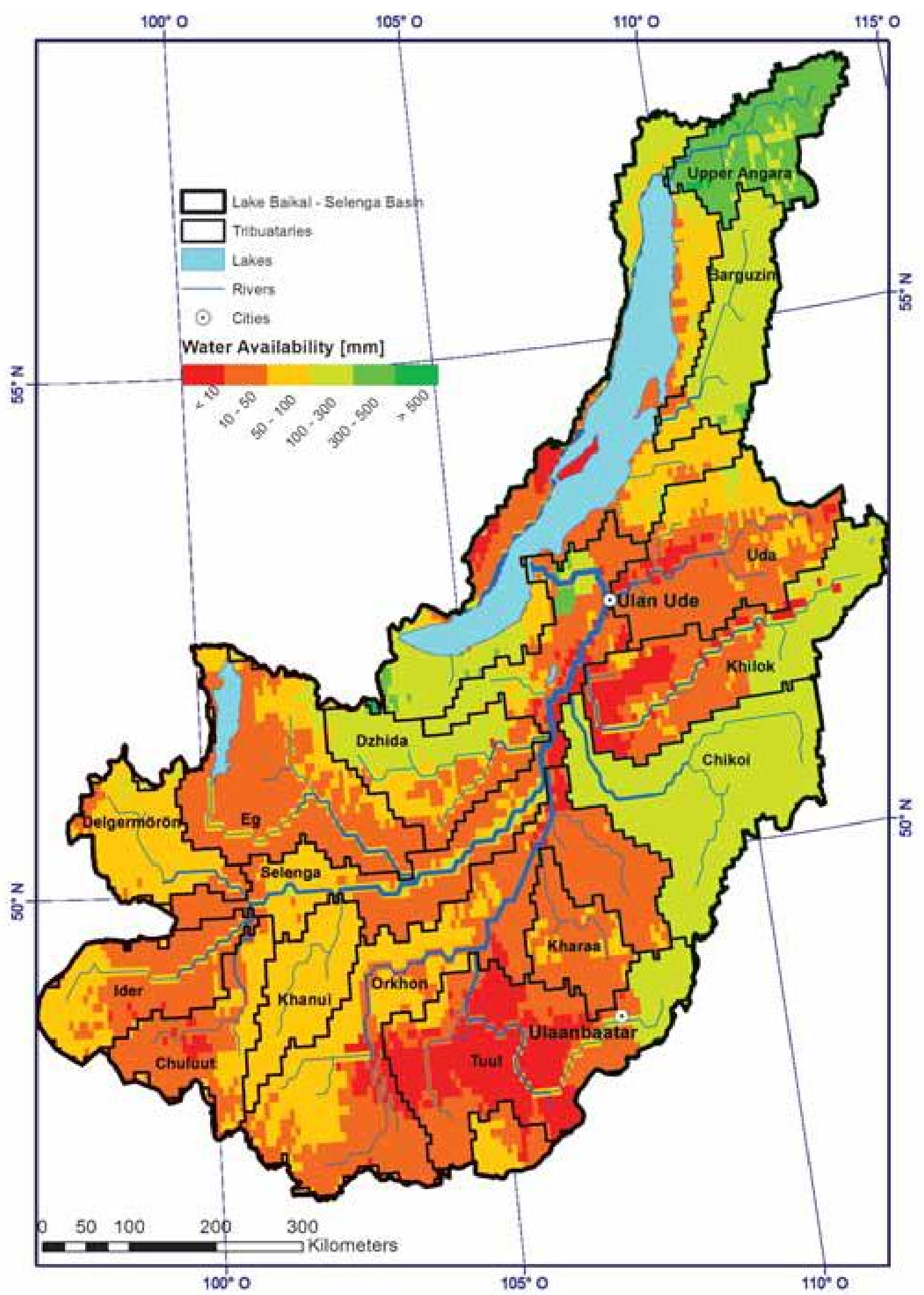

Fig. 1. Modelled mean water availability in the Selenga-Baikal Basin (1971-2000). 
21st century. Similarly, a realistic estimate for future water availability in the entire Selenga - Baikal Basin would need to be based on a model capable of recognizing the interplay of different drivers (such as changes in temperature, precipitation and land use). One particular challenge in the context of this transboundary catchment is differences in the quality and availability of input data for the Mongolian and Russian parts of the basin.

\section{Hydrological regime of the Kharaa - Orkhon - Selenga River System}

Despite considerable differences in absolute discharge quantities, the Kharaa, Orkhon and Selenga Rivers show a large interannual uniformity in their discharge pattern (Table 2). The hydrograph of all three rivers is characterized by very low winter discharge and two major runoff periods in April/May and July/August.

Stream flow increases rapidly from March to April and is related to thawing processes affecting snow cover, water in the soil and the subsurface, and groundwater stored in icings [Sloan \& Van Everdingen, 1988; Woo et al., 2000]. For the Kharaa River Basin, Wimmer et al. [2009] estimated that the melt of snow covers contributes only $5-6 \mathrm{~mm}$ to runoff due to the high sublimation rates. As snow melt cannot make up the entire stream flow during spring, the remaining part must be formed by soil and subsurface water as well as by the melting of aufeis. Since soils and the shallow subsurface are depleted at first, only small volumes of excess water in the soils are expected to remain in spring. This points to the importance of river icings. It is known that ice shields on subarctic rivers strongly contribute to spring discharge [Hu \& Pollard, 1997]. As melting progresses, the discharge rate gradually increases. This is consistent with the exponential increase of observed stream flow. Once snow and ice have melted in May, river discharge decreases.

With the beginning of the summer rainfall period in June and July, stream flow rises instantly in response to precipitation events. Rainfall in summer contributes mainly to groundwater flow and less to direct flow. Contrastingly, the melt of snow covers produces a considerable amount of direct runoff. The reason for that is that the infiltration and water holding capacity of the soils is increased when the active layer thaws in summer [Bolton 2006]. During that time, the water storages in the subsurface are filled. For the Kharaa, Orkhon and Selenga, about half of the annual runoff occurs during the summer season (June-August). Therefore, a chief cause for the variations in the runoff is the variability of summertime precipitation [Berezhnykh et al., 2012]. From October on, when temperature drops below $0^{\circ} \mathrm{C}$, snow becomes the dominant form of precipitation. Relatively low amounts of snowfall result in the depletion of groundwater and soil storages and the exponential decrease of stream flow in late autumn and winter.

Table 2. Seasonality of discharge for the Kharaa, Orkhon and Selenga Rivers

\begin{tabular}{|c|c|c|c|c|c|c|}
\hline \multirow{2}{*}{ River } & \multirow{2}{*}{ Period } & \multirow{2}{*}{$\begin{array}{l}\text { Mean annual } \\
\text { runoff, } \mathrm{m}^{3} / \mathrm{s}\end{array}$} & \multicolumn{4}{|c|}{$\begin{array}{l}\text { Mean contribution of quarterly runoff } \\
\text { to total annual runoff }\end{array}$} \\
\hline & & & Jan-Mar & Apr-Jun & Jul-Sep & Oct-Dec \\
\hline Kharaa at Baruunkharaa & $1951-2001$ & 10,71 & $3,8 \%$ & $31,5 \%$ & $51,0 \%$ & $13,6 \%$ \\
\hline Orkhon at Sukhbaatar & 1950-2008 & 124,5 & $1,7 \%$ & $29,8 \%$ & $53,8 \%$ & $14,7 \%$ \\
\hline Selenga at Kabansk & $1971-2009$ & 863,77 & $3,5 \%$ & $29,5 \%$ & $51,3 \%$ & $15,6 \%$ \\
\hline
\end{tabular}

Sources: Mongolian Institute of Hydrology and Meteorology; MEGD, 2012; Russian Federal Service for Hydrometeorology and Environmental Monitoring - Roshydromet 


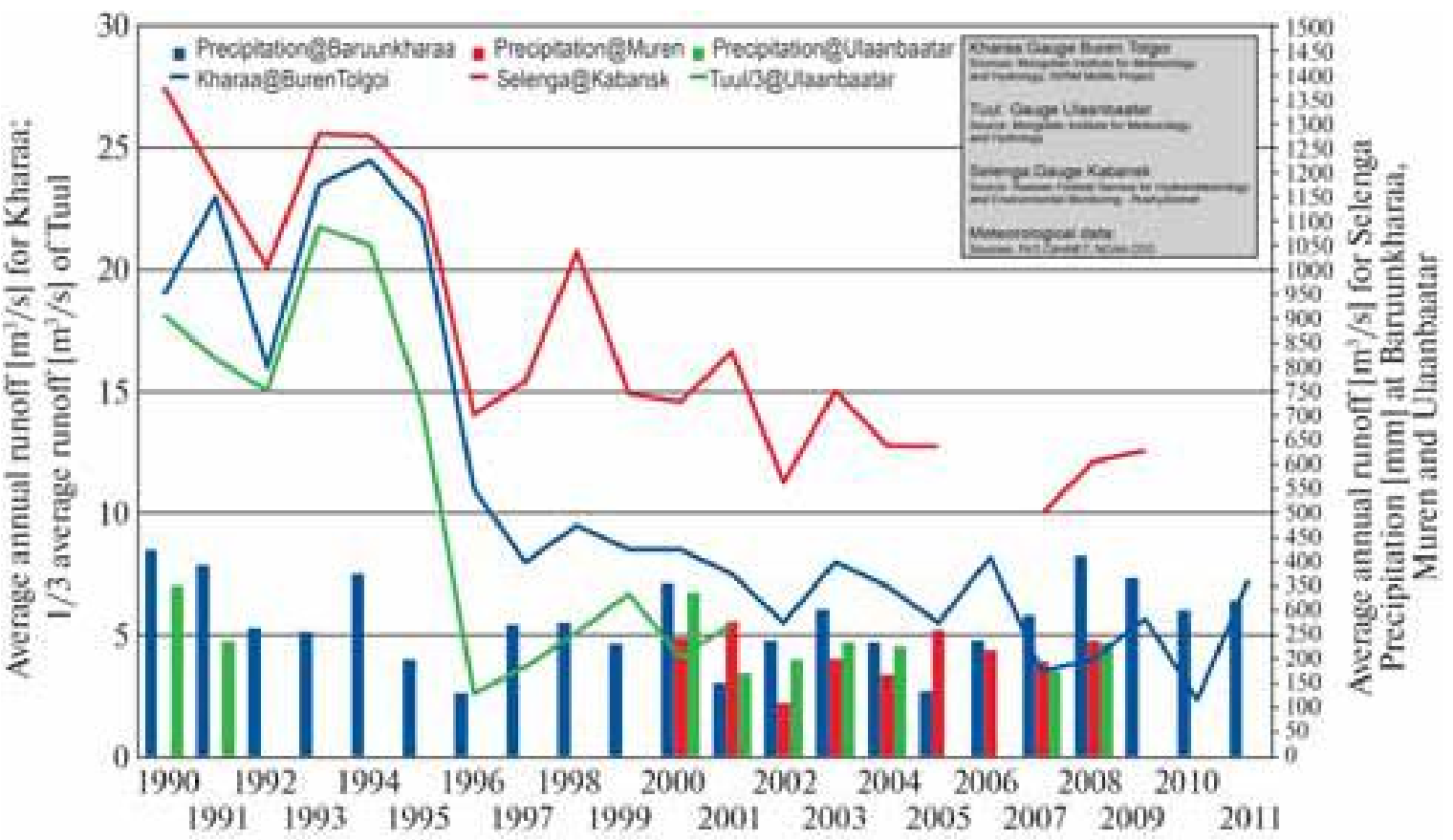

Fig. 2. Annual precipitation and runoff in the Kharaa, Tuul and Selenga Basins.

Interannual variations of the Selenga basin's renewable water resources are significant (Fig. 2). For the SelengaRiver and its western tributaries (Muren, Eg, Dzhida, Temnik), the mean annual flow is 2-3 times higher in high-discharge years as compared to low-water years. For the Selenga's eastern tributaries (Orkhon, Tuul, Chikoj, Khilok, Uda) this factor ranges between 4 and 5 [Semenov \& Myagmarzhav, 1977].

The low density of gauges and meteorological stations, data gaps and uncertainties related to data quality make it difficult to analyze the links between interannual precipitation and runoff dynamics. At first sight, it seems that the five year periods from 1990 to 1994 and from 2007 to 2011 were similarly wet in the Kharaa River Basin (Fig. 2; on average, 343 $\mathrm{mm}$ and $338 \mathrm{~mm}$ total annual precipitation at Baruunkharaa meteorological station, located in the center of the Kharaa River Basin respectively; long-term mean: $294 \mathrm{~mm}$ ). In contrast, annual runoff of the Kharaa, measured at the basin outlet at Buren Tolgoi, was comparatively high from 1990 to $1994\left(21,4 \mathrm{~m}^{3} / \mathrm{s}\right)$ and comparatively low from 2007-2011 $\left(4,5 \mathrm{~m}^{3} / \mathrm{s}\right.$; longterm mean: of $\left.12,4 \mathrm{~m}^{3} / \mathrm{s}\right)$. However, the distribution of precipitation in the region is known to be inhomogeneous [Menzel et al., 2011; Berezhnykh et al., 2012]. Keeping in mind the above mentioned data limitations, interpolated meteorological station data from the Global Precipitation Climatology Center suggest that the years between 1996 and 2011 were characterized by negative precipitation anomalies throughout most of the Selenga River Basin [Berezhnykh et al., 2012]. This would explain the significant decrease in mean annual discharge in the Kharaa, Selenga and Tuul between the first and the second half of the 1990s (Kharaa: $-44 \%$; Tuul: $-65 \%$; Selenga: $-28 \%)$. Moreover, the second half of the 1990s was characterized by longer than usual heat waves in the summer, and the warmest year of the century in Mongolia in 1998 [Batimaa et al., 2005]. Higher evapotranspiration therefore appears to be another plausible reason for a reduction in runoff formation.

\section{Land Use Changes and their Hydrological Relevance in the Kharaa River Model Region}

In the Kharaa River Basin (KRB), approximately $62 \%$ of the land is covered by grassland, $28 \%$ by forest, $9 \%$ by cropland and $1 \%$ by settlements (Fig. 3). Land use, which is spatially still dominated by grazing, is characterized by rapid changes in the recent 
past. Since the turn of the century, lifestock population has doubled and a similar development can be observed in agriculture since 2006/7. While the sawn area currently sums up to 50,000 ha, the total area under cultivation including fallows for crop rotation amounts to 110,000 ha. Simultaneously, the national government provides financial incentives to intensify production, based on the "3rd Campaign of re-claiming virgin lands" with the final objective to achieve food self-sufficiency [Priess et al., 2011]. At the same time, favourable market conditions in Ulaanbaatar and Darkhan seem to drive the fast expansion of vegetable production. The observed changes of the recent past imply several direct and indirect hydrological consequences. In terms of land

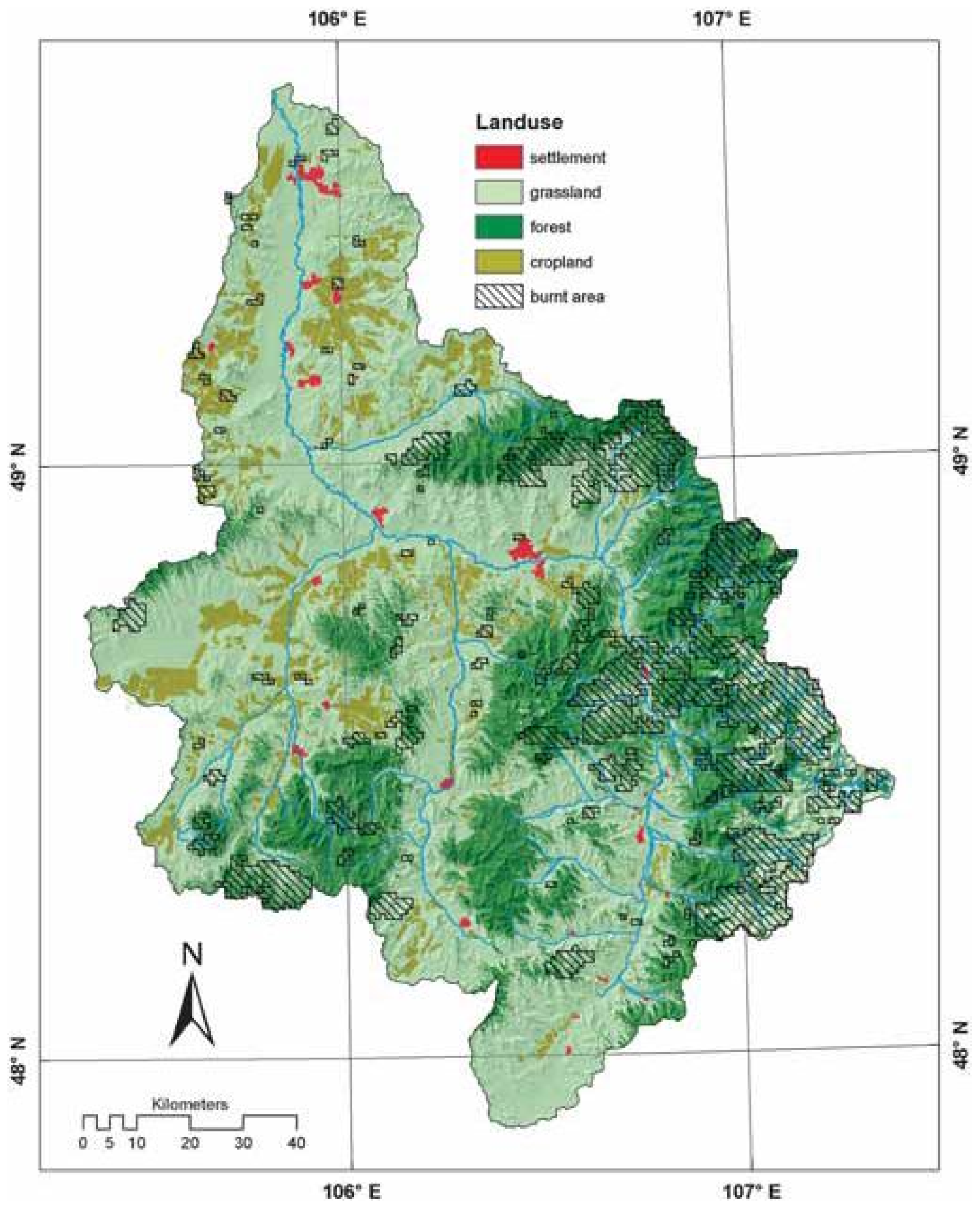

Fig. 3. Land cover map derived from Landsat TM for the year 2010, including areas affected by wildfires (MODIS). 
use, an increased competition for fertile and accessible land between herders and farmers can be observed, resulting not only in strongly increased fencing of fields, but also in expanding agricultural production from the river plains and valleys towards less favourable sloping lands and higher elevations. It can be assumed that the doubled livestock population causes degradation of grasslands, thereby altering not only biomass productivity but also evapotranspiration and runoff [Ishii \& Fujita, 2013]. All vegetable producers, and an increasing number of wheat and potato producers irrigate their land, currently 5,0006,000 ha. Depending on which assumptions we make for the ratios of different irrigation technologies in use (flooding, sprinklers, drip irrigation), the amount of water used for irrigation is in the range of 22-28 mio. $\mathrm{m}^{3}$ per year for the entire catchment. While government plans aim at doubling the area of irrigated areas to 10,000 ha, our scenarios based on more moderate rates of expansion observed in the past, result in 7000-8000 ha of irrigated land until 2050. Depending on irrigation area and the use of (improved) technologies, we expect an increase in water use to 35 to 45 mio. $\mathrm{m}^{3}$. This figure compares to an average of 80 mio. $\mathrm{m}^{3}$ during dry years.

While agricultural land use alters hydrological processes and currently emerges as an important consumer of water, a considerable part of the Kharaa's headwater regions, particularly in the eastern part, is still forested (Fig. 3). Besides the relevance for the water regime, Mongolian forests play an important role in preventing soil erosion, maintaining permafrost distribution and providing wildlife habitats [Tsogtbaatar, 2004]. However, deforestation is increasing due to the growing livestock numbers, increased demand for wood (timber and firewood) and increased occurrence of wildfires of anthropogenic origin. In addition, the rate of natural re-growth and successful reforestation is far too low and protection efforts often lack success due to inefficient management strategies and deficits regarding law enforcement [Tsogtbaatar, 2013]. Satellite based detection of wildfires based on MODIS fire data [Giglio et al., 2003] indicates that in total 200000 ha (which equates about 14\% of the forested area) have been affected by wildfires to a varying degree between April 2000 and May 2012 (Fig. 3). The quantification of hydrological implications of gradual and abrupt forest cover changes is generally difficult and requires careful exploration of hydrological components such as evapotranspiration, infiltration, runoff formation and water holding capacity.

A third important driver of landuse change in the region are mining activities. Especially gold mining requires large amounts of (ground-)water, which larger companies reuse from sedimentation ponds, while smaller companies and illegal extractors tend to use river water with motor pumps and open sedimentation cascades, with most of the used (and contaminated) water remaining in the catchment. The ponds are considered the key sources of net water losses from mining via evaporation (assuming well sealed ponds). In years of normal precipitation, the evaporation from open water surfaces of artificial lakes for irrigation and sedimentation ponds of gold mining companies combined (about 4.6 mio $\mathrm{m}^{3}$ from $\sim 550$ ha water surfaces) sum up to about $1 \%$ of the long-term river discharge, a value that may double or triple in dry or hot years with higher evaporation and reduced river discharge (see Fig. 2).

\section{Investigation of Hydrometeorological Processes in a Headwater Region and their Relevance at River Basin Scale}

Since a major part of the KRB lacks environmental information, hydrological investigations initially had to be based on few meteorological data from official stations, a time series of observed discharge at the basin outlet and the application of a robust hydrological model approach [Törnros \& Menzel, 2010]. After calibration, the model was applied to predict the water balance in the ungauged sub-catchments. As expected, the headwaters of the basin appear to act as regional water towers where substantial 
discharge volumes are produced [Menzel et al., 2011]. This is in sharp contrast to the dry steppe forelands with low to absent discharge formation.

Based on these findings, extensive field investigations were carried out in a mountainous sub-basin of the Kharaa. The Sugnugur river drains parts of the remote Khentii Mountains which stretch in the east of the Kharaa catchment and peak at about 2,800 $\mathrm{m}$ a.s.l. This sub-catchment includes the transition belt between the steppe, taiga and alpine ecotones and therefore includes a variety of environmental factors, e.g. snow storage, permafrost occurrence [Ishikawa et al., 2005] or forest distribution, which determine hydrological processes, water quality and water availability. Parts of the region represent a pristine boreal and mountain environment. It is assumed that they act as the major freshwater generating areas of the Kharaa catchment. However, there are several indicators of human impacts and climate variability on the ecosystem, the most serious are forest fires, leaving extensive areas with burned forest.

In 2011, a monitoring program was started in the Sugnugur sub-catchment focusing on hydro-meteorological behaviour along an altitudinal gradient (Fig. 4). During field campaigns in 2011 and 2012, soil temperature, soil moisture, meteorological parameters as well as the structure of the coniferous forests were monitored at various sites in the upper Sugnugur valley. The sites were selected according to a forest

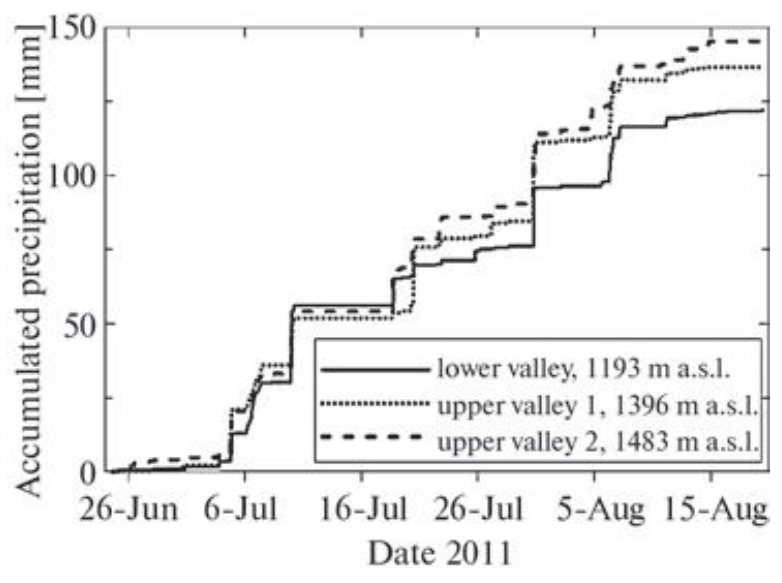

Fig. 4. Altitudinal precipitation gradient in the Sugnugur valley. health survey in which they were classified into three categories: 1) undisturbed / vital, 2) harmed through forest fire, 3) exclusively dead trees. In addition, unforested sites in the vicinity of the forest plots were selected for soil water and temperature monitoring. Results show that the unforested sites are free of permafrost since they are mostly on southern exposed slopes with high radiation intensities. Consequently, soil temperatures are comparatively high while soil infiltration rates and soil moisture are low. Runoff mainly occurs as fast surface flow during high-intensity precipitation events. Further, there are clear differences between the three forest categories. Under vital forest the active layer appears to be surprisingly shallow (i.e., permafrost is close to the soil surface), soil infiltration rates as well as the water retention potential are comparatively high. Delayed matrix flow in the well-developed organic layer and in the mineral horizon dominates. Besides, the depth of the active layer seems to increase with decreasing forest vitality, accompanied by warmer soil temperatures while soil moisture tends to decline. Runoff generation is influenced by a relocation of flow paths. Pipeflow occurs between the dead organic cover and the mineral horizon as well as along an effective network of deep flow paths which probably originate from root canals. Thus, the investigations support the hypothesis that forest disappearance alters water retention in the headwaters and thus water availability in the dry steppe zone. Climate change probably supports this process through additional warming and a decrease of snow cover which again reduces available soil water. The collected environmental data and the improved process understanding will finally lead to improved hydrological modelling of the entire Kharaa basin.

\section{WATER QUALITY AND ITS DETERMINANTS}

The Selenga River Basin is, by international standards, characterized by a relatively low population density of around 5 people $/ \mathrm{km}^{2}$. However, localized concentrations of 
population, an often poor state of urban waste water infrastructures, high livestock densities in the riverine floodplains and largescale mining activities are potential threats to the aquatic ecosystems of the Selenga, its tributaries and Lake Baikal. In the recent past, water quality monitoring in the Mongolian and Russian parts of the river basin was not harmonized, which is maybe best reflected by the fact that the two countries are located in the upstream and downstream sections of the river system, and thus faced different water resources problems. This followed by discrepancies in water policy objectives and understanding of monitoring purposes.

\section{Industry and Mining-Related Pollution in the Selenga River Basin}

A state inventory for surface water in Mongolia conducted in 2003 showed that even though most rivers in the country were in relatively pristine condition, at least 23 rivers in 8 provinces were morphologically changed and/or polluted due to mining activities [Batsukh, 2008], including the Selenga and several of its tributaries. Chemical analyses of water and sediment samples taken in the Selenga River Basin showed a relative enrichment in comparison to natural background conditions (detected for suspended and bottom sediments) and maximal permissible concentrations (detected for dissolved load) with several elements, including $\mathrm{As}, \mathrm{Cd}, \mathrm{Mn}, \mathrm{Pb}$ and $\mathrm{Zn}$ (Table 3).

Most of As and $\mathrm{Zn}$ are transported as dissolved load, whereas $\mathrm{Cd}, \mathrm{Mn}$ and $\mathrm{Pb}$ are almost completely adsorbed by suspended solids. One source of the relatively high concentrations of As appears to be the lignite deposits in Northern Mongolia. The industrial centers of Erdenet (Mongolia) and Zakamensk (Russia) are important sources of heavy metal pollution. Mercury, which is regarded as a serious threat to water resources near mining operations in the area [Batsukh, et al. 2008], never exceeded maximum permissible concentrations in suspended sediments. However, due to historical use of mercury for gold extraction, high concentrations were found in bottom sediments near major mining operations in the Dzida river in Russia (up to 1,6 times) and Kharaa river basin (up to 20 times in Borroo river) in Mongolia.

\section{Anthropogenic Nutrient Enrichment in the Kharaa River Basin}

In recent years human activities have lead to increasing concentrations of phosphorus and nitrogen in the Kharaa River. In order to monitor this trend, we have used surveillance data provided by Mongolian authorities for two monitoring sites (upstream and downstream of the city of Darkhan) and complemented this monthly to bi-monthly dataset with additional monitoring from 2006 to 2012 to observe gradients of nutrient concentrations along the main river course and its tributaries, extending from the headwaters in the Khentii Mountains to the outlet of the river basin at Buren Tolgoi. This multi-year sampling survey has been carried out along the Kharaa River in spring, summer and autumn each year in order to investigate seasonal variations but also to create a time series of quality assured data. Nutrients were determined after filtration by photometry and standard cuvette tests (Hach-Lange Inc.) with standard solutions as blind tests. The systematic evaluation of the nutrient species for phosphorus (total phosphorus, soluble reactive phosphorus) and nitrogen (nitrate, nitrite, ammonium, total nitrogen) provides a comprehensive picture of recent nutrient trends. For the evaluation of results and determination of water quality classes we used the Mongolian surface water classification 143/a/352 [MNE \& $\mathrm{MH}, 1997]$, the Mongolian drinking water standard MNS 900: 2005 [MNCS\&M, 2005] and $\mathrm{WHO}$ guidelines as comparisons. The latter two references are relevant since river water is frequently used for drinking and food preparation in rural areas.

The evaluation of concentrations based on Mongolian Surface Water Guidelines resulted in a 'very good' to 'good' chemical 
Table 3. Heavy metal loads of water and sediments in the Selenga River System

\begin{tabular}{|c|c|c|c|c|c|c|c|}
\hline River & Period & Sample & As & $\mathrm{Cd}$ & Mn & $\mathrm{Pb}$ & $\mathrm{Zn}$ \\
\hline \multicolumn{3}{|c|}{ MPC } & 0,05 & 0,005 & 0,01 & 0,006 & 0,01 \\
\hline \multicolumn{3}{|c|}{$C_{\text {ucc }}$} & 2 & 0,102 & 527 & 17 & 52 \\
\hline \multirow{6}{*}{ Selenga delta } & & $\mathrm{DL}$ & 1,5 & 0,01 & 51 & 6,9 & 44 \\
\hline & 2011, August & SL & 16.6 & 1.81 & 1483.7 & 219.6 & 534.1 \\
\hline & & BS & 7.2 & 0.25 & 635 & 19 & 95 \\
\hline & & $\mathrm{DL}$ & 0.4 & 0.027 & 32 & 2 & 9.2 \\
\hline & 2012, June & $S L$ & 12.71 & 0.34 & 1237.11 & 29.21 & 85.91 \\
\hline & & BS & 2.7 & 0.17 & 472.54 & 19 & 48 \\
\hline \multirow{6}{*}{$\begin{array}{l}\text { Selenga, Russian- } \\
\text { Mongolia border }\end{array}$} & & $\mathrm{DL}$ & 2.1 & 0.01 & 41 & 0.64 & 53 \\
\hline & 2011, August & $\mathrm{SL}$ & 22.8 & 0.42 & 2155.7 & 38.3 & 125.7 \\
\hline & & BS & 3.1 & 0.19 & 581 & 14 & 45 \\
\hline & & $\mathrm{DL}$ & - & - & - & - & - \\
\hline & 2012, June & SL & - & - & - & - & - \\
\hline & & $B S$ & 3.6 & 0.2 & 666.20 & 18 & 59 \\
\hline \multirow{6}{*}{$\begin{array}{l}\text { Djida River, below } \\
\text { Modonkul mining }\end{array}$} & & DL & 0.25 & 1.1 & 93 & 0.26 & 180 \\
\hline & 2011, August & SL & 10.0 & 10.82 & 1803.3 & 704.9 & 1639.3 \\
\hline & & BS & 9.6 & 9.7 & 1859 & 500 & 730 \\
\hline & & DL & 0.4 & 0.077 & 6.2 & 0.36 & 20 \\
\hline & 2012, June & $\mathrm{SL}$ & 8.33 & 2.13 & 3033.33 & 40.00 & 156.67 \\
\hline & & BS & 3.9 & 0.37 & 526.76 & 36 & 81 \\
\hline \multirow{6}{*}{$\begin{array}{l}\text { Orkon river dow- } \\
\text { stream }\end{array}$} & & $\mathrm{DL}$ & 5.3 & 0.005 & 0.15 & 0.05 & 0.5 \\
\hline & 2011, August & $\mathrm{SL}$ & 11.5 & 0.23 & 1113.0 & 29.6 & 80.0 \\
\hline & & $\mathrm{BS}$ & 4.5 & 0.22 & 519 & 14 & 59 \\
\hline & & $\mathrm{DL}$ & 2.9 & 0.02 & 34 & 0.45 & 1.5 \\
\hline & 2012, June & $S L$ & 12.20 & 0.09 & 1890.24 & 17.07 & 67.07 \\
\hline & & BS & 5 & 0.15 & 565.49 & 15 & 45 \\
\hline \multirow{6}{*}{$\begin{array}{l}\text { Tuul river below } \\
\text { Ulaanbaatar }\end{array}$} & & $\mathrm{DL}$ & 6.7 & 0.005 & 0.15 & 0.05 & 0.5 \\
\hline & 2011, August & SL & 2.6 & 0.05 & 289.0 & 6.4 & 17.3 \\
\hline & & BS & 6.6 & 0.24 & 643 & 16 & 66 \\
\hline & & DL & 6.7 & 0.005 & 0.15 & 0.05 & 0.5 \\
\hline & 2012, June & SL & 2.6 & 0.05 & 289.0 & 6.4 & 17.3 \\
\hline & & BS & 6,6 & 0,24 & 643 & 16 & 66 \\
\hline \multirow{2}{*}{$\begin{array}{l}\text { Kharaa river at } \\
\text { outlet (Buren } \\
\text { Tolgoi) }\end{array}$} & 2010, May & SL & 12.9 & 0.59 & 1305.0 & 22.8 & 136.3 \\
\hline & 2010, September & $S L$ & 13.38 & 0.53 & 1404.0 & 18.3 & 124.8 \\
\hline
\end{tabular}

$\mathrm{DL}=$ dissolved load $(\mathrm{mg} / \mathrm{l}), \mathrm{SL}=$ suspended load $(\mathrm{mg} / \mathrm{kg}), \mathrm{BS}=$ bottom sediments $(\mathrm{mg} / \mathrm{kg})$

MPC - maximal permissible concentrations according to Russian laws (mg/l)

$C_{\text {ucc }}$ - lithosphere averages (mg/kg; according to Wedepohl, 1995)

DL should be compared to MPC; BS and SL should be compared to $C_{\text {ucc }}$ 
status for nutrients in the headwaters. However, in the mid- and more significantly in the downstream sections of the Kharaa River concentrations of total phosphorus and total nitrogen lead to a 'moderate' or 'poor' status according to the above cited guidelines. The loads of orthophosphate-P at the basin outlet (Buren Tolgoi gauge) show a constant increase during the observation period (Fig. 5).

The remarkable increase from 33 to $57 \mathrm{t} /$ yr orthophosphate-P is an indication for the increasing nutrient release into Kharaa River by diffuse sources, mainly urban areas without connection to treatment plants. For total nitrogen concentrations and loads a similar trend could be observed [Hofmann et al., 2013]. As a result of nutrient emission modelling with the MONERIS model, urban settlements are the main sources for nitrogen and phosphorus emissions contributing about 55\% (nitrogen) and $52 \%$ (phosphorus) of the total emissions [Hofmann et al., 2011]. The proportion of point sources (WWTP) was much higher for nitrogen (30\% of total $\mathrm{N}$ emissions) than for phosphorus (15\% of total Permissions). Since only $35 \%$ of the total population in the river basin are connected to WWTPs, unconnected urban areas represent an important proportion of the total emissions (38\% of phosphorus and 25\% of nitrogen emissions).With regard to phosphorus, river bank erosion is another significant

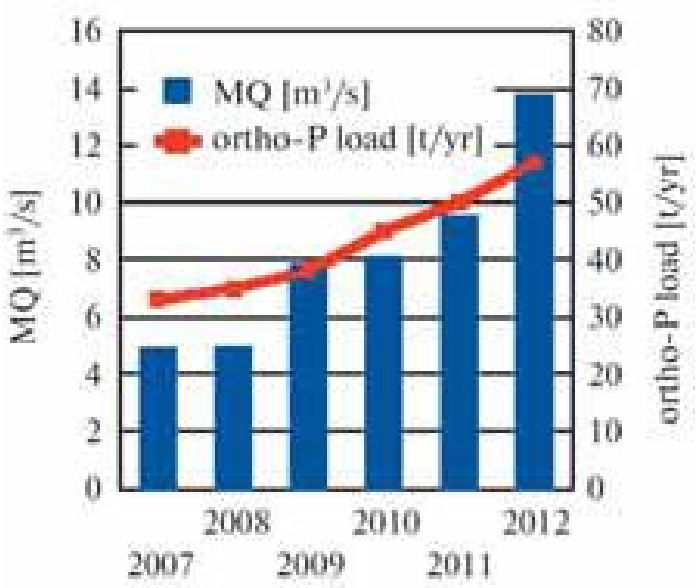

Fig. 5. Observed discharge and orthophosphate-P loads at the outlet of KRB (2007 to 2012). source of nutrient release [Hartwig et al., 2012; Theuring et al., 2013]. This process is triggered by an increasing degradation of riparian vegetation due to high livestock densities with free access to the running waters. The rising nutrient levels have a significant eutrophication potential in the Kharaa River and functional shifts of the macroinvertebrates and fish fauna have been observed already [Hofmann et al., 2011]. These upstream trends also help to explain the nutrient enrichment further downstream in the Selenga's main stem. While for the 1970s, phosphorus concentrations between 2 and $13 \mu \mathrm{g} / \mathrm{l}$ were reported, recent levels are between 5 and 19 Mg/l [Sorokovikova et al., 2013].

\section{Identification of Fine Sediment Sources and Impacts of their Influx}

Recent studies on the main drivers and sources of fine sediment input in the Khaara River catchment using isotope based sediment source fingerprinting techniques [Hartwig et al., 2012, Theuring et al., 2013] identified riverbank erosion $(74,5 \%)$ and surface upland erosion $(21,7 \%)$ as the main contributors to the suspended fine sediment load (grain size $<10 \mu \mathrm{m}$ ) in the catchment. Although agricultural areas in middle and lower parts of the KRB are prone to surface erosion due to temporary vegetation cover and fallow periods, low precipitation, gentle slopes and wide floodplains in the valley bottom mean that surface-eroded sediments rarely reach the river system. By contrast, riverbank erosion is a significant process (Fig. 6) at the catchment scale. Although naturally high in a unregulated, meandering lowland river, a lack of riparian vegetation caused by high grazing intensities strongly enhances riverbank erosion. In fact, only 20 to $35 \%$ of the riverbanks in the lower catchment still have near-natural vegetation. In the pristine upstream areas of the catchment, which are usually forested, surface erosion is a more prominent contributor $(36,2 \%)$ to the total load. Even though riparian vegetation is still intact in these regions, 


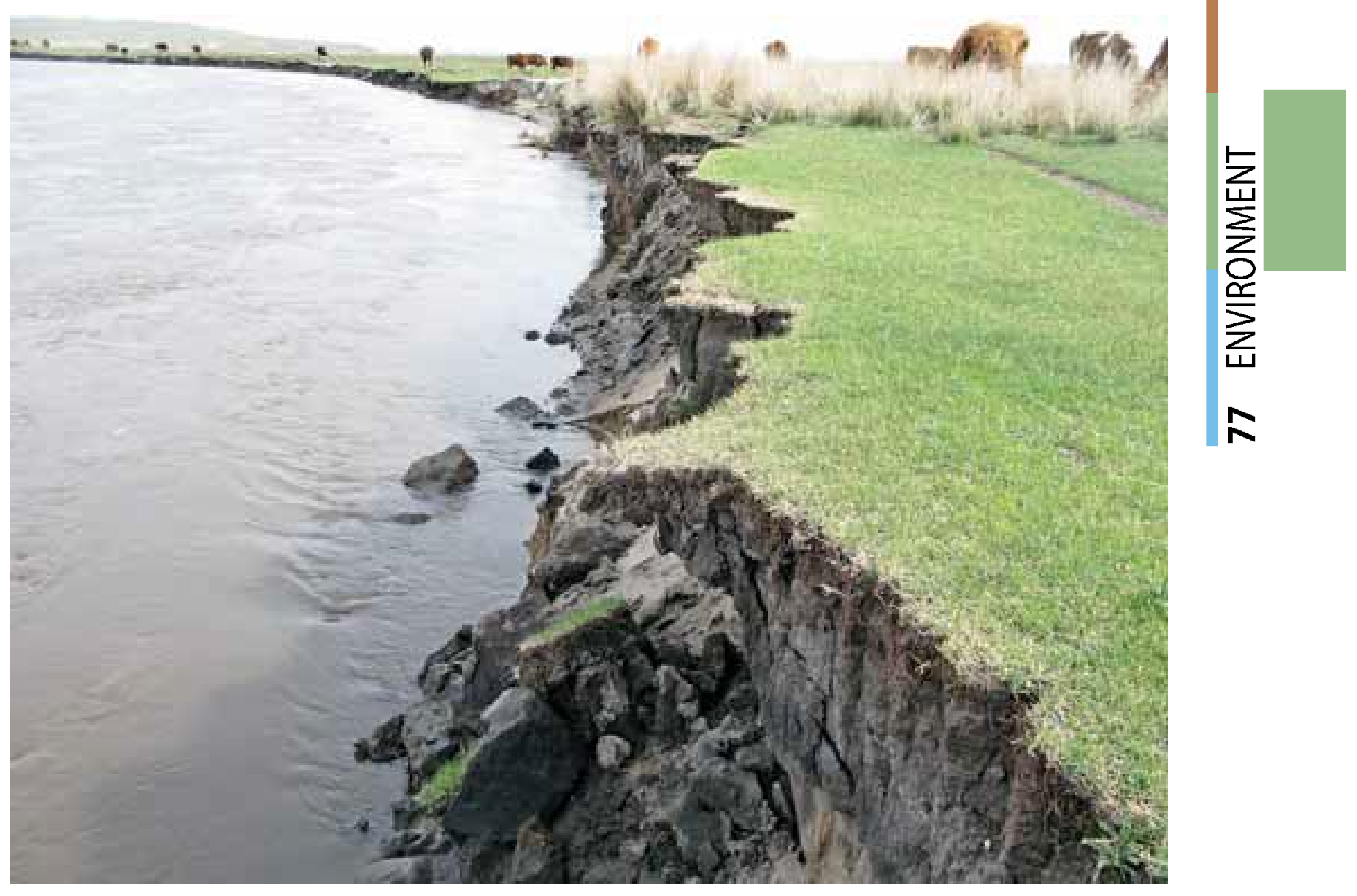

Fig. 6. Riverbank erosion on the Kharaa.

$63,8 \%$ of the suspended sediments stem from riverbank erosion.

Sediment budget calculations using the SedNet model and the revised universal soil loss equation (RUSLE) estimate an annual flow of 16,2 kt of suspended sediments at the catchment outlet, comparing well with measured data (mean: 20,3 kt/a) [Theuring et al., 2013]. However, as shown before, surface erosion estimates are only of limited use to investigate fine sediment input in river systems in this region, due to the dominance of riverbank erosion. These findings, which are characteristic for catchments in semiarid steppe regions, have important implications for the understanding of fine sediment generation in the SelengaBaikal river basin. In terms of management options, they shift the focus of erosion prevention measures from agriculture to animal husbandry as a key determinant of sediment influxes.
Besides acting as an agent for heavy metal pollution input from the terrestrial environment into the river system, increased suspended fine sediment loads also affect the aquatic ecosystem e.g. in terms of physical riverbed clogging. The fine sediments either remain suspended or infiltrate into the interstices of the riverbed, causing severe effects on functions of the surface and subsurface water compartments like primary production, hydrological connectivity, biogeochemical turnover and habitat. Therefore, an intensive monitoring program was conducted on the microscale spanning from relatively pristine (river kilometer 79) to heavily stressed reaches (river kilometer 120 and 128, see Fig. 7) of the Kharaa River [Hartwig et al., 2012]. The measurements included parameters on the hydromorphology, hydrology, water quality and biology of both the surface and subsurface water compartments. It was shown that especially the sediment input of the tributary draining the second largest and 


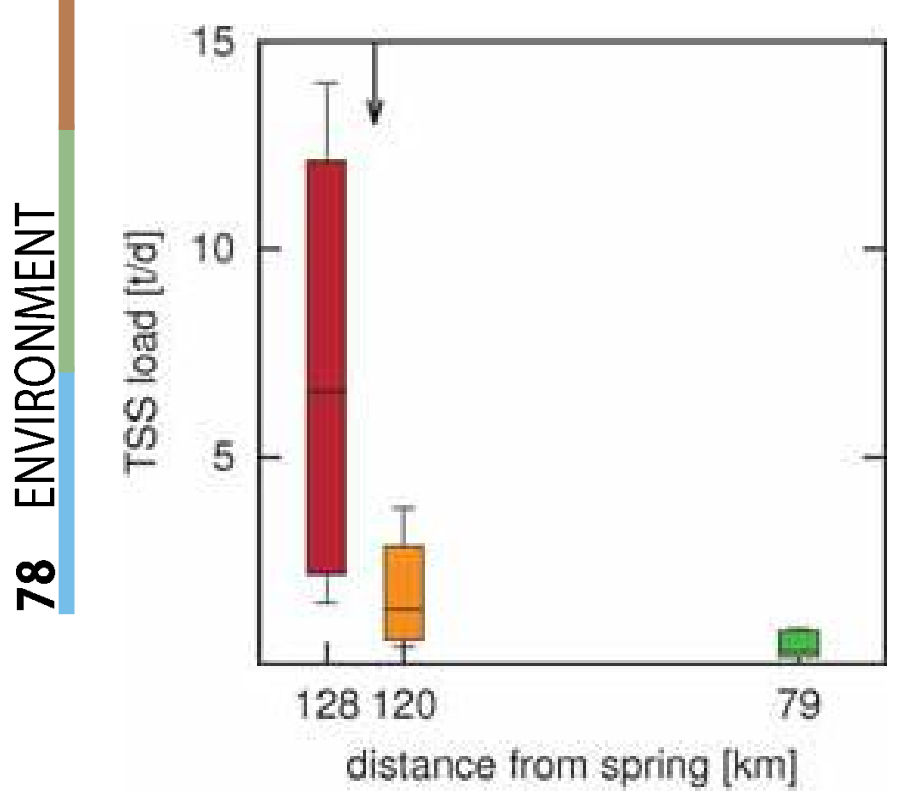

Fig. 7. Total suspended sediment loads in the Kharaa during medium flow (arrow indicates confluence of Zagdelin Gol).

intensively used sub-catchment of Zagdelin Gol affected almost all considered functions. The algae succession and whole stream productivity was decreased compared to the reach upstream the confluence. Through a high fine particulate fraction in the uppermost sediment layer the vertical connectivity declined. Thus, the penetration depth of surface water rich in oxygen and organic carbon into the riverbed decreased, lowering the potential for biogeochemical metabolism by means of depth. However, the higher fine sediment fraction may have provided more surface area for microbes as oxygen respiration rates were found to be in the same range as upstream the confluence. Habitat quantity and quality for higher organisms was concluded to be affected as well. As the assessment of the macroinvertebrate community revealed [Hofmann et al., 2011], this degradation is permanent as indicated by a shift in the functional composition of the community. This leads to the conclusion that either the high discharge events were not strong enough to break off the clogging layer or that the suspended sediment input was high and long-lasting. Although the sediment load during mid-flow events at the more pristine region was low, an increased fraction of fine sediment was observed in the deeper riverbed sediment. The big sediment pore space and high vertical downward flow velocities found here may have increased the intake of suspended material during flood events. Due to this susceptibility for an inner clogging, fine sediment input needs to be controlled in order to protect the aquatic ecosystem.

\section{CONCLUSIONS}

Water management in the Selenga-Baikal Basin, which is of global importance as a freshwater reservoir and unique ecosystem, faces several challenges. The Selenga and its tributaries do not only constitute a transboundary river basin with a lack of harmonized monitoring; the large size, low population densities and challenges related to the political and economic transformation also result in a scarcity of environmental data. In such a situation, a comprehensive monitoring of water-resources is almost prohibitive. Therefore, one promising approach is to combine intensive monitoring in a representative model region with a more synoptic monitoring in the larger basin. This strategy seems plausible for the basins of the Kharaa and Selenga rivers which are comparable with regard to the (bio-)physical and socio-economic environment [Karthe et al., 2013].

This paper integrated findings of research activities focusing on the micro (local), meso (Kharaa) and macro (Selenga-Baikal) scale. With regard to water availability, the most relevant drivers include climate and land use changes. In contrast to a longterm (20 th century) trend of increasing water availability, the period from 1995 onwards was unusually dry for the entire Selenga River Basin. For the future, a predicted increase in precipitation may outweigh the effects of rising temperatures and evapotranspiration. However, land use changes appear to be equally important. While remote sensing data can help to survey such changes over large areas, only field investigations at the site scale can help to understand the impacts of land cover changes on hydrologically relevant 
processes (such as infiltration, surface runoff, evapotranspiration or water storage) in detail. Observations in the Sugnugur valley, a relatively pristine headwater region in the Kharaa River Basin, indicate that the loss of forest cover (due to logging, land clearance and wildfires) in one sub-region is a major threat to water availability even at river basin scale.

With regard to water quality, important stressors include fine sediment influxes, pollution of water and sediments with heavy metals, and -at moderate but increasing levels- nutrient inputs. In particular for the Mongolian part of the Selenga River Basin, high livestock densities in the riverine floodplains are an important cause of degrading vegetation and consequently riverbank erosion. The release of toxic substances into surface water bodies and their accumulation in sediments can frequently be related to mining activities. With regard to nutrient loads, population growth in urban areas and the poor state of wastewater treatment plants are of concern. Even though most of the surface water bodies cannot be considered eutrophic, there is a clear trend of rising nutrient levels.

From a management perspective, the integration of findings from the Selenga River Basin shows that present and future problems appear to be comparable in (sub)basins of different scales. Therefore, an effective monitoring concept for the macroscale Selenga-Baikal Basin could consist of an intensive monitoring in a selected model region (such as the Kharaa
River Basin) and synoptic surveys at the large scale. At the same time, solutions that have been proven effective in this model region have a high potential for successful duplication in comparable locations in the Selenga-Baikal Basin.

\section{ACKNOWLEDGMENTS}

Work in the Kharaa River Basin was conducted in the context of the research and development project "Integrated Water Resources Management in Central Asia: Model Region Mongolia", funded by the German Federal Ministry of Education and Research (BMBF) in the framework of the FONA (Research for Sustainable Development) initiative (grant no. 033L003). They acknowledge the support provided by the Project Administration Jülich (PTJ) and the BMBF/International Bureau in the context of the "Assistance for Implementation" (AIM) scheme.

Work in the Lake Baikal Basin was implemented under support of RussianMongolian complex biological expedition RAS-MAS, the Russian Geographical Society grant "Expedition Selenga-Baikal", Russian Fund for Basic Research Grant 12-05-33090.

German-Russian cooperation was supported by the International Bureau of the German Federal Ministry of Education and Research in the context of grant RU 12/039 "Sustainable water management in the Baikal-Selenga Basin: Development of an integrated monitoring concept for a transboundary river catchment with multiple stressors".

\section{REFERENCES}

1. Alcamo, J.M., Döll, P., Henrichs, T. et al. (2003). Development and testing of the WaterGAP2 global model of water use and availability. Hydrological Sciences Journal, Vol. 48 (3), pp. 317-337.

2. Anisimov, O., Reneva, S. (2006). Permafrost and Changing Climate:The Russian Perspective. Ambio, Vol. 35 (4), pp. 169-175. DOl: http://dx.doi.org/10.1579/0044-7447(2006)35\%5B1 69:PACCTR\%5D2.0.CO;2 
3. aus der Beek, T., Flörke, M., Lapola, D. M. et al. (2010). Modelling historical and current irrigation water demand on the continental scale: Europe. Advances in Geosciences, N 27, pp. 79-85. DOI: http://dx.doi.org/10.5194/adgeo-27-79-2010

4. Batimaa, P., Tatsagdorj, L., Gombluudev, P., Erdenetsetseg, B. (2005). Observed climate change in Mongolia. AIACC Working Paper, N 12, Assessments of Impacts and Adaptations to Climate Change (AIACC).

5. Batsukh, N., Dorjsuren, D., Batsaikhan, G. (2008). The water resources, use and conservation in Mongolia. First national report. Ulaanbaatar: National Water Committee.

6. Bereznykh, T., Marchenko, O., Abasov, N., Mordvinov, V. (2012). Changes in the summertime atmospheric circulation over East Asia and formation of long-lasting low-water periods within the Selenga river basin. Geography and Natural Resources, Vol. 33(3), pp. 61-68. DOl: http://dx.doi.org/10.1134/S1875372812030079

7. Bolton, W.R. (2006). Dynamic Modeling of the Hydrological Processes in Areas of discontinuous Permafrost. Dissertation at the University of Alaska, Fairbanks, USA.

8. Chalov, S.R., Zavadsky A.S., Belozerova, E.V. et al. (2012). Suspended and Dissolved Matter Fluxes in the Upper Selenga River Basin: Synthesis. Geography, Environment, Sustainability, Vol. 02 (05), pp. 78-94.

9. Clarke, A., Murphy, E.J., Meredith, M.P. et al. (2007). Climate change and the marine ecosystem of the western Antarctic Peninsula. Philosophical Transactions of the Royal Society London B: Biological Sciences,Vol. 362 (1477), pp. 149-166. DOl: http://dx.doi. org/10.1098\%2Frstb.2006.1958

10. Döll, P., Kaspar, F., Lehner, B. (2003). A global hydrological model for deriving water availability indicators: model tuning and validation. Journal of Hydrology, Vol. 270 (1-2), pp. 105-134. DOI: http://dx.doi.org/10.1016/S0022-1694(02)00283-4

11. Flörke, M., Kynast, E., Bärlund, I. et al. (2013). Domestic and industrial water uses of the past 60 years as a mirror of socio-economic development: A global simulation study. Global Environmental Change,Vol. 23 (1), pp. 144-156. DOl: http://dx.doi.org/10.1016/j. gloenvcha.2012.10.018

12. Garmaev, E.J., Khristovorov, A.B. (2010). Water Resources of the Rivers of the Lake Baikal Basin: Basics of Their Use and Protection. Novosibirsk: Academic Press "Geo", 301 p (In Russian).

13. Giglio, L.; Descloitres, J.; Justice, C.O. and Kaufman, Y.J. (2003): An enhanced contextual fire detection algorithm for MODIS. Remote Sensing of Environment 87 (2-3): 273-282. DOl: http://dx.doi.org/10.1016/S0034-4257(03)00184-6

14. Hagemann, S., Chen, C., Haerter, J.O. et al. (2011). Impact of a statistical bias correction on the projected hydrological changes obtained from three GCMs and two hydrology models. Journal of Hydrometeorology, Vol. 12 (4), pp. 556-578. DOl: http://dx.doi. org/10.1175/2011JHM1336.1

15. Hartwig, M., Theuring, P., Rode, M., Borchardt, D. (2012). Suspended sediments in the Kharaa River catchment (Mongolia) and its impact on hyporheic zone functions. En- 
vironmental Earth Sciences,Vol. 65 (5), pp. 1535-1546. DOl: http://dx.doi.org/10.1007/ s12665-011-1198-2

16. Hofmann, J., Hürdler, J., Ibisch, R, Schäffer, M., Borchardt, D. (2011). Analysis of Recent Nutrient Emission Pathways, Resulting Surface Water Quality and Ecological Impacts under Extreme Continental Climate: The Kharaa River Basin (Mongolia). International Review of Hydrobiology, Vol. 96 (5), pp. 484-519. DOl: http://dx.doi.org/10.1002/iroh.201111294

17. Hofmann, J., Rode, M., Theuring, P. (2013).Recent developments in river water quality in a typical Mongolian river basin, the Kharaa case study.[Online]. Proceedings of the IAHS-IAPSO-IASPEI Assembly, Gothenburg, Sweden. Available from: http://iahs-iapsoiaspei2013.com/Abstracts.aspx?252102 [Accessed 11.03.2014].

18. Hu, X.,Pollard, W.H. (1997). The Hydrologic Analysis and Modelling of River Icing Growth, North Fork Pass, Yukon Territory, Canada. Permafrost and Periglacial Processes.Vol. 8 (3), pp. 279-294. DOI: http://dx.doi.org/10.1002/(SICI)1099-1530(199709)8:3<279::AIDPPP260>3.0.CO;2-7

19. IPCC - Intergovernmental Panel on Climate Change (2007). Climate Change 2007: The Physical Science Basis. Contribution of Working Group I to the Fourth Assessment Report of the Intergovernmental Panel on Climate Change. Cambridge and New York: Cambridge University Press.

20. Ishii, R., Fujita, N. (2013). A Possible Future Picture of Mongolian Forest-Steppe Vegetation Under Climate Change and Increasing Livestock: Results from a New Vegetation Transition Model at the Topographic Scale. In: Yamamura, N., Fujita, N. (Ed.) (2013).The Mongolian Ecosystem Network. Environmental Issues Under Climate and Social Changes, pp. 65-82.

21. Ishikawa, M., Sharkuu, N., Zhang, Y. et al. (2005). Ground Thermal and Moisture Conditions at the Southern Boundary of Discontinuous Permafrost, Mongolia. Permafrost and Periglacial Processes, Vol. 16 (2), pp. 209-216. DOI: http://dx.doi.org/10.1002/ppp.483

22. Karthe, D., Chalov, S., Theuring, P., Belozerova E. (2013). Integration of Meso- and Macroscale Approaches for Water Resources Monitoring and Management in the BaikalSelenga-Basin. In: Chifflard, P., Cyffka, B., Karthe, D., Wetzel, K.-F. (2013). Beiträge zum 44. Jahrestreffen des Arbeitskreises Hydrologie, Augsburg: Geographica Augustana, pp. 90-94.

23. Karthe, D., Theuring, P., Borchardt, D., Hufert, F. (2012). An Integrated Water Monitoring Concept Designed for a Multi-Stressor Environment: Experiences from the Kharaa River Basin, Mongolia. In: Tserashchuk, M. (Ed.) (2012). Proceedings of the IWA Young and Senior Water Professionals Conference St Petersburg, 2012. Part I, pp. 40-48.

24. Kasimov, N., Lychagin, M., Chalov, S. (2010). Development of a scientific basis for the monitoring and prediction of transboundary pollutant transports in the Selenga River Catchment and their influences on Lake Baikal. Report on project no. 11.519.11.5008 of the Russian Ministry of Education and Science.

25. Malsy, M., aus der Beek, T., Eisner, S., Flörke, M. (2012). Climate change impacts on Central Asian water resources. Advances in Geosciences, Vol. 32, pp. 77-83. DOI: http://dx.doi. org/10.5194/adgeo-32-77-2012 
26. MEGD - Ministry for Environment and Green Development (2012). Orkhon River Basin Integrated Water Management Plan. Ulaanbaatar.

27. Menzel, L., Hofmann, J., Ibisch, J. (2011). Untersuchung von Wasser- und Stoffflüssen als Grundlage für ein Integriertes Wasserressourcenmanagement im Kharaa-Einzugsgebiet, Mongolei. Hydrologie und Wasserbewirtschaftung, Vol. 55 (2), pp. 88-103.

28. MNCS\&M - Mongolian National Center of Standardizations \& Meteorology (2005). Mongolian drinking water standard MNS 900: 2005. Ulaanbaatar.

29. MNE\&MH - Ministry of Nature and Environment \& Ministry of Health (1997). Surface water classification 143/a/352. Ulaanbaatar: Joint order of the Mongolian Ministry of Nature and Environment and Ministry of Health.

30. MoMo Consortium (2009). Integrated Water Resources Management for Central Asia: Model Region Mongolia (MoMo). Case Study in the Kharaa River Basin. Final Project Report.

31. Piani, C., Weedon, G. P., Best, M. et al. (2010). Statistical bias correction of global simulated daily precipitation and temperature for the application of hydrological models. Journal of Hydrology, Vol. 395 (3-4), pp. 199-215. DOl: http://dx.doi.org/10.1016/j.jhydrol.2010.10.024

32. Potemkina, T. (2011). Tendencies of formation sediment load of Baikal general tributaries at the 20th century and early 21st century. Russian Meteorology and Hydrology, Vol. 36 (12), pp. 63-71. DOl: http://dx.doi.org/10.3103/S1068373911120077

33. Priess, J., Schweitzer, C., Wimmer, F. et al. (2011). The consequences of land-use change and water demands in Central Mongolia - an assessment based on regional land-use policies. Land Use Policy, Vol. 28 (1), pp. 4-10. DOI: http://dx.doi.org/10.1016/j.landusepol.2010.03.002

34. Semenov, V., Myagmarzhav, B. (1977). Hydrological regime of the Selenga River Basin. Leningrad: Hydrometioizdat, 235 p. (In Russian).

35. Shimaraev, M., Kuimova, L., Sinyukovich, V., Tsekhanovskii, V. (2002). Manifestation of Global Climatic Changes in Lake Baikal during the 20th Century. Doklady Earth Sciences, Vol. 383A (3), pp. 288-291.

36. Sloan, C.E., van Everdingen, R.O. (1988). Region 28, Permafrost Region. In: Back, W., Rosenshein, J.S., P.R. Seaber (Eds.) (1988). The Geology of North America, pp. 263-270. Boulder, Colorado: The Geological Society of America.

37. Sorokovikova, L., Popovskaya, J., Tomberg, I. et al. (2013). The Selenga river water quality on the border with Mongolia at the beginning of the 21st century. Meteorology and Hydrology, N 2, pp. 92-103 (In Russian).

38. Theuring, P., Rode, M., Behrens, S., Kirchner, G., Jha, A. (2013). Identification of fluvial sediment sources in a meso-scale catchment, Northern Mongolia. Hydrological Processes, Vol. 27 (6), pp. 845-856. DOl: http://dx.doi.org/10.1002/hyp.9684.

39. Thorslund, J., Jarsjö, J., Chalov, S., Belozerova, E. (2012). Gold mining impact on riverine heavy metal transport in a sparsely monitored region: the upper Lake Baikal Basin 
case. Journal of Environmental Monitoring, Vol. 14 (10), pp. 2780-92. DOl: http://dx.doi. org/10.1039/c2em30643c

40. Törnros, T., Menzel, L. (2010). Heading for knowledge in a data scarce river basin: Kharaa, Mongolia. In: Herrmann, A., Schumann, S. (Eds.) (2010). Status and Perspectives of Hydrology in Small Basins, pp. 270-275. Wallingford: IAHS Publication 336.

41. Tsogtbaatar, J. (2004). Deforestation and reforestation needs in Mongolia. Forest Ecology and Management, Vol. 201 (1), pp. 57-63. DOl: http://dx.doi.org/10.1016/j.foreco.2004.06.011

42. Tsogtbaatar, J. (2013). Deforestation and Reforestation of Degraded Forestland in Mongolia. In: Yamamura, N., Fujita, N. (Ed.) (2013). The Mongolian Ecosystem Network. Environmental Issues Under Climate and Social Changes, pp. 83-98. Tokyo: Springer Japan.

43. Verzano, K. (2009). Climate change impacts on flood related hydrological processes: Further development and application of a global scale hydrological model. Reports on Earth System Science 71-2009. Hamburg: Max Planck Institute for Meteorology.

44. Wedepohl, K. (1995). The composition of the continental crust. Geochimica et Cosmochimica Acta, Vol. 59 (7), pp. 1217-1232. DOl: http://dx.doi.org/10.1016/00167037(95)00038-2

45. Weedon, G. P., Gomes, S., Viterbo, P. et al. (2011). Creation of the WATCH Forcing Data and Its Use to Assess Global and Regional Reference Crop Evaporation over Land during the Twentieth Century. Journal of Hydrometeorology, Vol. 12 (5), pp. 823-848. DOI: http:// dx.doi.org/10.1175/2011JHM1369.1

46. Wimmer, F., Schlaffer S., aus der Beek, T., Menzel, L. (2009). Distributed modelling of climate change impacts on snow sublimation in northern Mongolia. Advances in Geosciences, N 21, pp. 117-124. DOl: http://dx.doi.org/10.5194/adgeo-21-117-2009

47. Woo, M.-K., Marsh, P., Pomeroy, J.W. (2000). Snow, frozen soils and permafrost hydrology in Canada, 1995-1998. Hydrological Processes, Vol. 14 (9), pp. 1591-1611. DOl: http:// dx.doi.org/10.1002/1099-1085(20000630)14:9<1591::AID-HYP78>3.0.CO;2-W

48. WWAP - World Water Assessment Program (2012). The United Nations World Water Development Report 4: Knowledge Base. Paris: UNESCO.

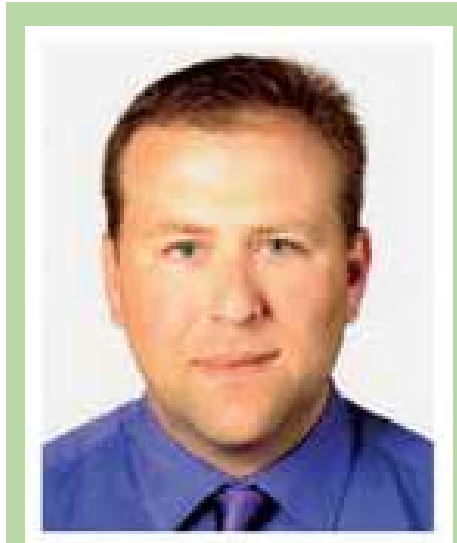

Daniel Karthe studied Geography at Mannheim University, Germany, and Presidency College, Kolkata, India and obtained his doctoral degree at the Institute of Geography at Göttingen University, Germany, in 2009. Since 2010, he has been working as a scientist at the Helmholtz Centre for Environmental Research in Magdeburg, Germany. The focus of his research is on hydrology, Integrated Water Resources Management (IWRM), water, sanitation and hygiene (WASH), urban water management, water quality monitoring and medical geography. He is the speaker of the working group of Hydrology of the German Geographical Society and author of papers related to different aspects of water resources management in Central Asia. 


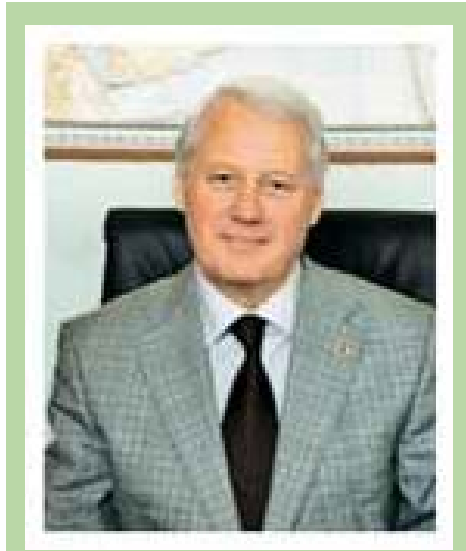

Nikolay S. Kasimov, Professor, Dean of the Faculty of Geography, Moscow State University, Head of the Department of Landscape Geochemistry and Soil Geography, Full Member of the Russian Academy of Sciences. He serves as First Vice-President of the Russian Geographical Society. He is among the leading experts in environmental geochemistry, biogeochemistry, geochemistry of subaqual ecosystems, and paleo-geochemistry. He coordinated numerous international projects funded by the Russian Foundation for Fundamental Research and Ministry of Education and Science, British-Russian educational projects, Dutch-Russian (NWO), Flemish-Russian projects etc. At present he is the leader of the Russian Geographical Society project on Selenga-Baikal research. He is the author of about 300 scientific works, including: Landscape Geochemistry (1999, coauthor A.I. Perel'man) and Landscape Ecogeochemistry (2013).

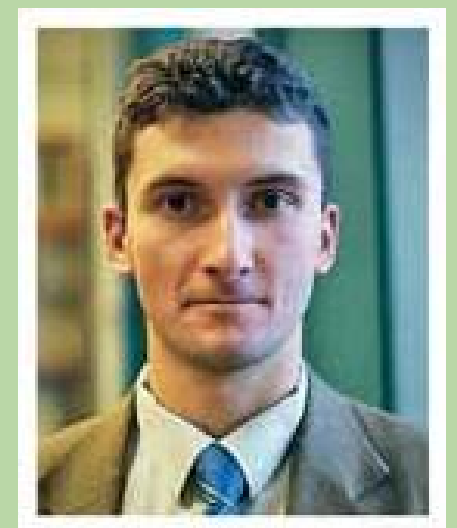

Sergey R. Chalov received his M.S. and Ph.D degrees in Fluvial Processes and Hydrology from the Faculty of Geography, Lomonosov Moscow State University, in 2004 and 2007 respectively. His research interests are focused on Water resources, Fluvial processes, Environmental Hydraulics and Sedimentation with special emphasis on hydrodynamics, stream communities and biodiversity, transboundary rivers, sediment transport and sediment hazards, and environmental risk analysis for rivers. He is the author of 90 journal papers and 4 books.

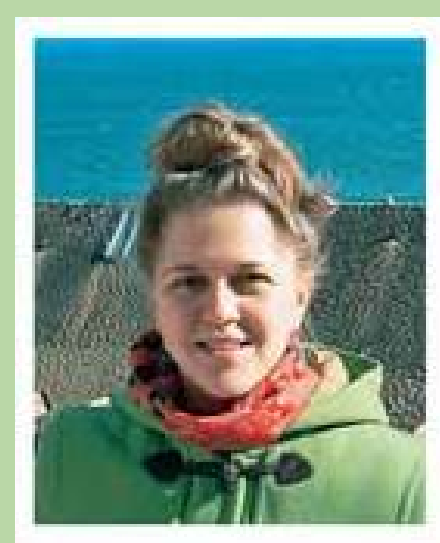

Galina L. Shinkareva graduated from the Lomonosov Moscow State University in 2012. At present she is Ph.D. student at the Department of Landscape Geochemistry and Soil Geography, Faculty of Geography. Her scientific interests are focused on geochemistry of aquatic landscapes. Main publications: Water Resources assessment of the Selenga-Baikal river system (2013, with co-authors); Environmental state of aquatic systems in the Selenga River basin (2012, with co-authors).

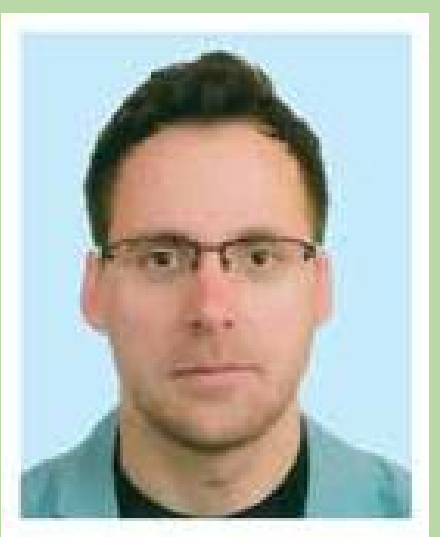

Marcus Malsy has been working at the Center for Environmental Systems Research, Kassel, Germany since 2010. He graduated from Carl von Ossietzky University, Oldenburg, Germany with a master degree in landscape ecology. His research focuses on impacts of global change on water resources. He worked on large scale hydrological modelling in Central Asia within the "Integrated Water Resources Management - Model Region Mongolia" project. Currently he works on large scale water quality modelling as part of the UNEP funded "Assessment of World Water Quality to Meet the Global Water Quality Challenge" project. 


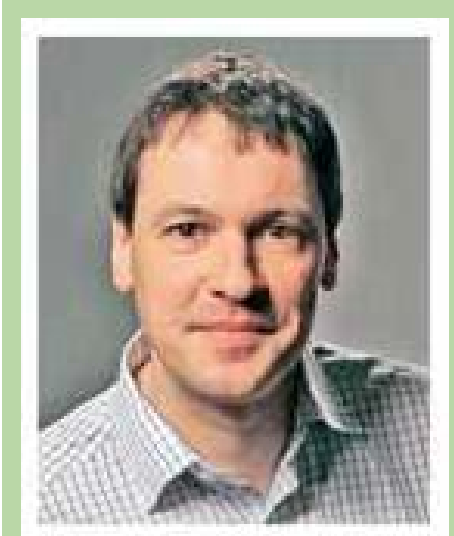

Lucas Menzel received his PhD at the Federal Institute of Technology ETH in Zurich (Switzerland). From 1998-2004 he was a postdoctoral researcher at the Potsdam-Institute for Climate Impact Research (PIK) before he joined the Center for Environmental Systems Research (CESR) at Kassel University as leader of the Water Group. Since 2009 he is Full Professor at the Department of Geography, University of Heidelberg, Germany, where he leads the Hydrology and Climatology Section. His research interests include water scarcity, drought, evapotranspiration, permafrost hydrology, as well as the impact of global environmental change on the regional hydrology, with special focus on Central Europe, the Middle East and Central Asia.
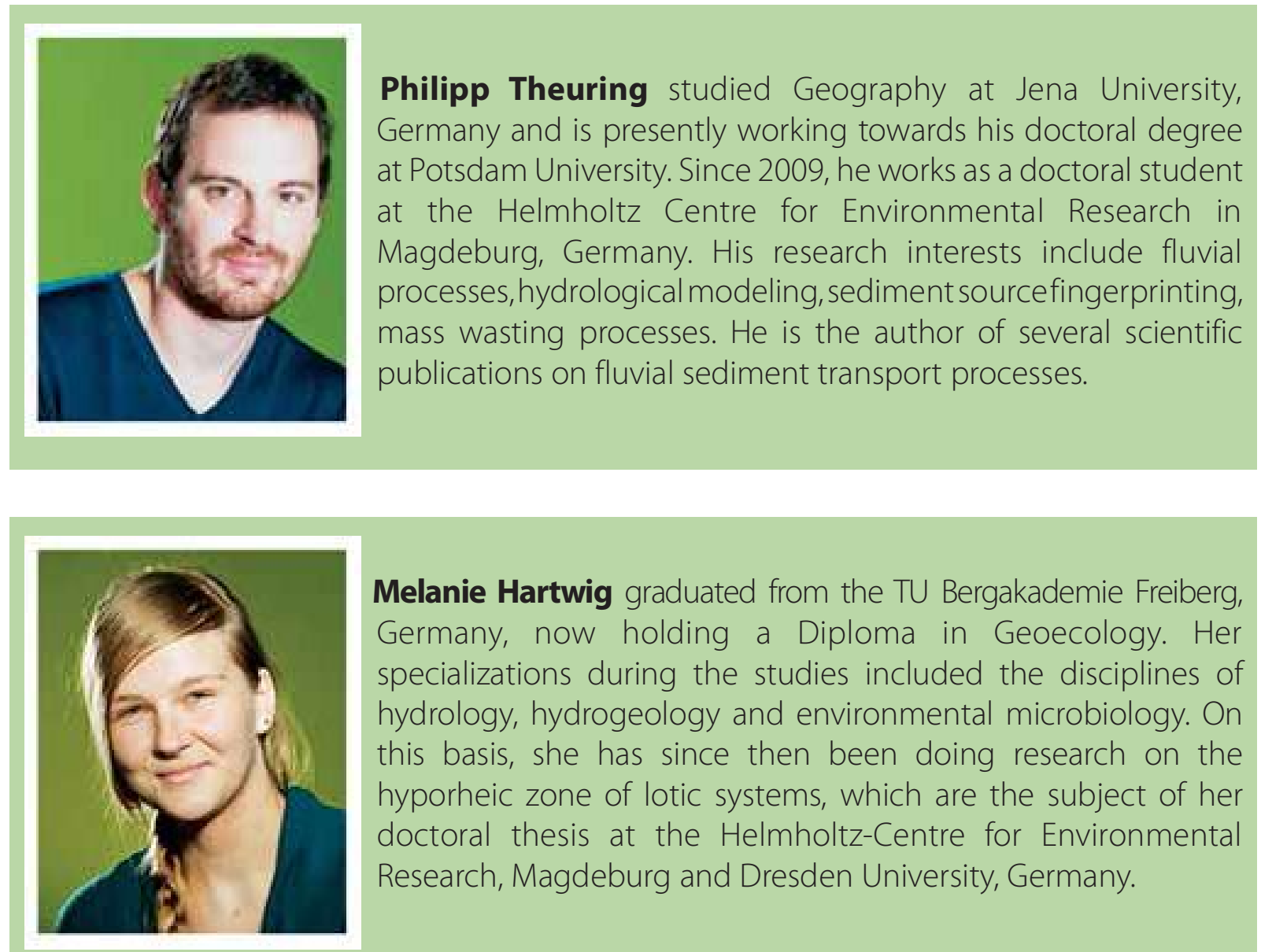

Melanie Hartwig graduated from the TU Bergakademie Freiberg, Germany, now holding a Diploma in Geoecology. Her specializations during the studies included the disciplines of hydrology, hydrogeology and environmental microbiology. On this basis, she has since then been doing research on the hyporheic zone of lotic systems, which are the subject of her doctoral thesis at the Helmholtz-Centre for Environmental Research, Magdeburg and Dresden University, Germany.

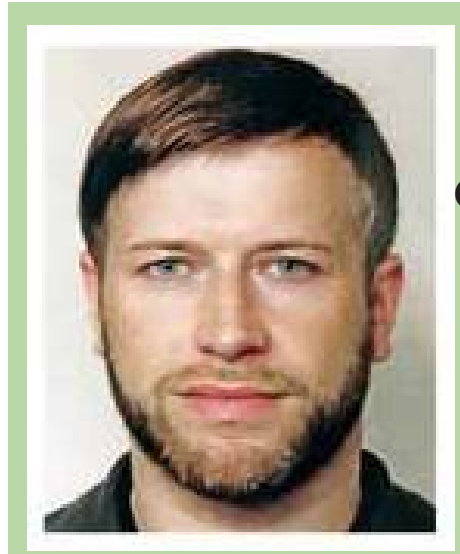

Christian Schweitzer is scientist at the Department of Computational Landscape Ecology, Helmholtz Centre for Environmental Research 

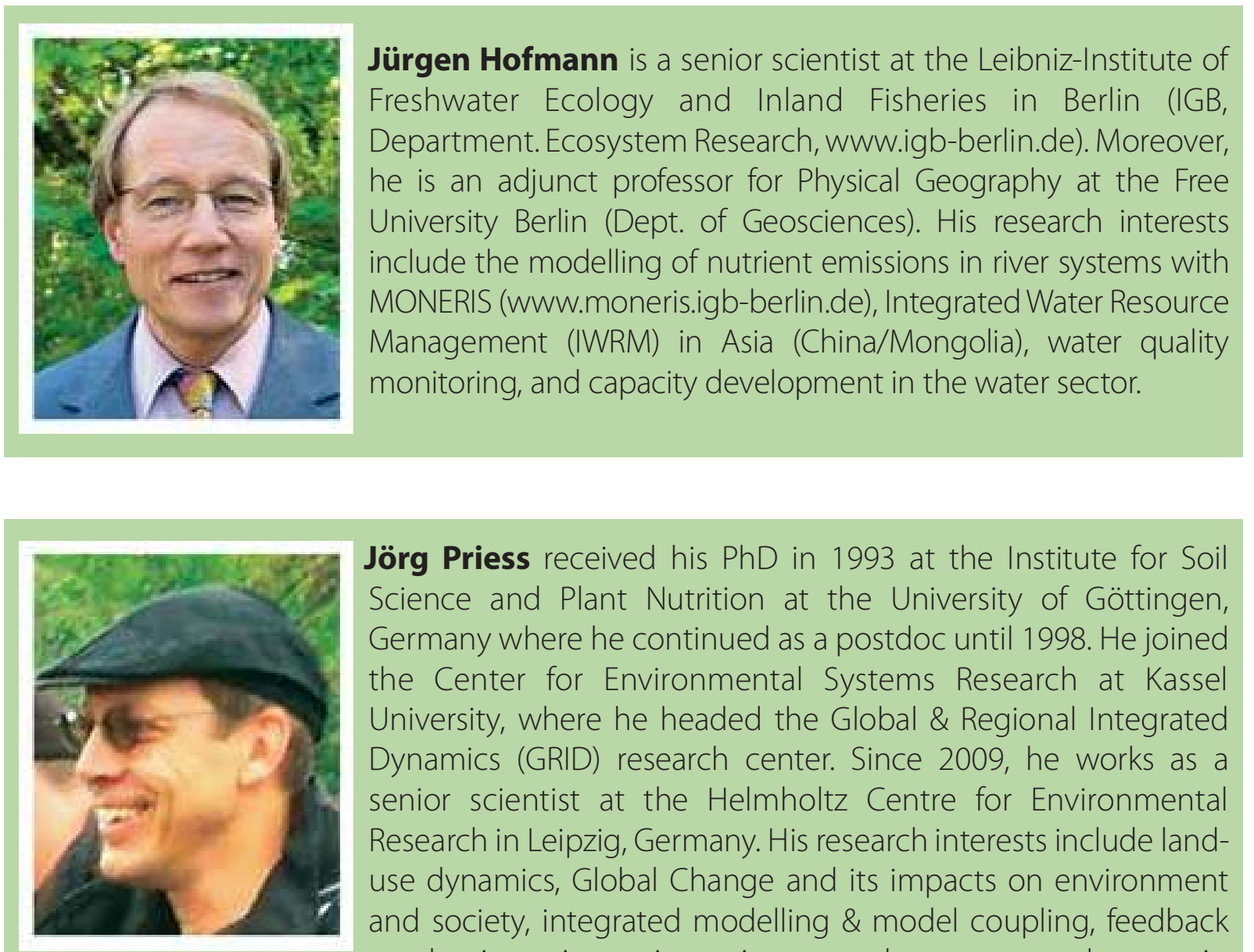

Jörg Priess received his PhD in 1993 at the Institute for Soil Science and Plant Nutrition at the University of Göttingen, Germany where he continued as a postdoc until 1998. He joined the Center for Environmental Systems Research at Kassel University, where he headed the Global \& Regional Integrated Dynamics (GRID) research center. Since 2009, he works as a senior scientist at the Helmholtz Centre for Environmental Research in Leipzig, Germany. His research interests include landuse dynamics, Global Change and its impacts on environment and society, integrated modelling \& model coupling, feedback mechanisms in socio-environmental systems and scenario development \& analysis. He has authored numerous papers on these topics in high-ranking international journals.

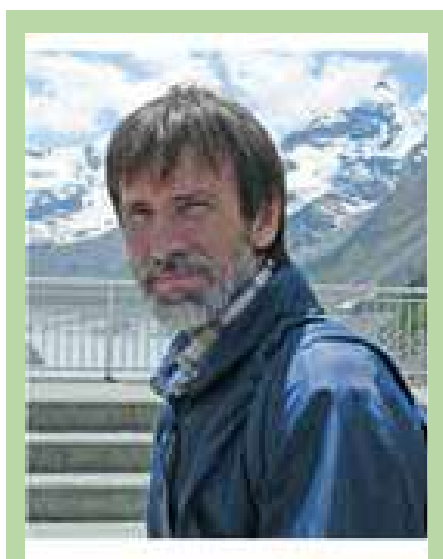

Mikhail Lychagin is Associate Professor of the Department of Landscape Geochemistry and Soil Geography, Faculty of Geography, Lomonosov Moscow State University. His research interests focus on environmental geochemistry, aquatic systems, environmental monitoring and GIS. For 20 years he has been involved into the comprehensive research within the Caspian Sea basin: environmental consequences of the Caspian Sea-level fluctuations, environmental geochemical state of aquatic systems in the Volga delta and the Northern Caspian. 